\title{
Margaret Cavendish's Mythopoetics: By Way of Introduction
}

\author{
Sandro Jung
}

Line Cottegnies's “The 'Native Tongue' of the 'Authoress': The Mythical Structure of Margaret Cavendish's Autobiographical Narrative" is one of the few recent, scholarly discussions to have examined the mythical structure and strategies of Margaret Cavendish's writings. ${ }^{1}$ Her discussion of Cavendish's autobiographical work, its strategies for embedding the narrative in a generic tradition of autobiographical writing, and her construction of myth is insightful and productive, and it deserves to be extended to comprise the complexity of Cavendish's entire oeuvre. Cavendish's many generically hybrid works offer themselves to such an examination in a way that few others do, and this special issue of English Studies focuses on a varied exploration of the genres, contexts and discourses of her works and the ways in which these entail and promote authorially determined scripts of identity construction. In this introduction, I aim will delineate some of the ways in which scholarship can engage with Cavendish's preoccupation with self-fashioning - the construction of an image that would ensure her mythified cultural existence as inscribed in her writings, the anecdotes of others, and the metatextual attempts at coming to terms with the polyvalence of the images she offers to her readers. I shall suggest a number of ways in which Cavendish's constructions of myths in her self-fashioning and in the fashioning of the worlds that she creates can contribute to understanding her significance in terms of what French critics such as Véronique Gély and Pierre Brunel, especially in the latter's recent Mythopoétique des Genres (2003), have understood in the context of mythopoeia, that is, the creative literary reworking of myth and its ability to generate new genres of writing or the creation of new 
myths by means of genres previously associated with mythic inscription. The striking prominence of epic features in Cavendish's works are not so much evidence of the destabilised seventeenth-century epic impulse, as these formal traits confirm the author's deep sensitivity to, and awareness of, literary forms and its traditions. The often multi-layered integration of multiple narratives of the creation and their adaptation for the performative purposes that Cavendish would have anticipated are central intergeneric and intermodal building blocks in an authorial panopticum inhabited by Cavendish herself. Through the author's proto-auratic conjured or physical presence, especially during the reading or performative process (within the salon culture sketched by James Fitzmaurice's contribution), the aggregate meaning of her writings would have been synthesised and rendered intelligible and cohesive to her readers and those with whom she interacted directly. This process of unifying ostensibly different, contradictory aspects of life, epistemology, or the "parts" of knowledge is centrally examined in Isabelle Clairhout's and my contribution to this special issue; it also underpins Erin Webster's exploration of the philosophical, Descartian contexts of Cavendish's writing.

In Benjaminian terms, the cult value of Cavendish's works consisted in their inextricable connection with the uniquely constructed mythic personae that she fashioned throughout her life and with which the frontispiece of her works is iconographically inscribed. Irrespective of whether Cavendish appears as the romancical historiographer of her husband's fame, as she is portrayed in Emily Griffiths Jones's contribution, or whether she appears as the natural philosopher developing her own, unique philosophical system, Cavendish frequently relies on the conventions of romance to fashion her various personae. Griffiths Jones and Lisa Sarasohn convincingly unravel in which ways Cavendish deploys discursive conventions to relate herself to other mythic and proto-epic figures of suffering and heroism as her husband, the Duke of Newcastle. Rebecca Bullard, by contrast, explores 
the issue of miscellaneity in her bibliographical contribution and indicates novel ways of understanding the ways in which the miscellaneous make-up of Cavendish's textual presence can be absorbed into an overall view of unity.

Even a little explored work such as Natures three Daughters, Beauty, Love, and Wit, Parts I and II (1662) reveals the concern with identity-formation and self-definition that is so central to Cavendish's myth-making. In this respect, Cavendish's use of a plethora of mythological and rhetorical intertexts can be explored productively through a consideration of the contexts of performativity and genre and a relating of her transhistorical allegorical pageants to the tripartite configuration borne of Nature: the sisters Beauty, Wit, and Love. In order to understand the complex dynamics that Cavendish establishes between Nature, Beauty, and Love and the other allegorical characters - especially those who negotiate the polyphonously conceived and societally applied notions of love-it is useful to examine her personifying practice and the ways in which she uses a non-secular type of then already secularised concepts such as courtship, marriage, and love to reflect a woman's struggle to achieve self-realisation. Formalist approaches, especially to Cavendish's drama, are likely to draw out hitherto neglected generic constructions, in the process establishing the importance of the allegorical chorus and the debate initiated not only by means of the figures such as Tell-Truth and Detractor and emotions such as envy and jealousy; also, the figure of Mademoiselle Grand Esprit, possibly an emanation of Wit, retains a genealogical link of kinship with them, but—oracle-like — is able to formulate questions, especially regarding man, the answering of which ranges across a large number of themes that shed further light on the complex intertwining of Cavendish's mythico-human realm of philosophical inquiry.

While Cavendish has often been credited with providing a vision of femininity that is self-assured and characterised by ideals of self-governance and self-empowerment, especially where (romantic) love is concerned, this gender-based branch of scholarship has inadequately 
accounted for the author's potent symbolism. Specifically, scholars have not explored that the world that Cavendish and the characters she fashions inhabit a realm that awkwardly negotiates the nexus between spirituality and secularism. The performative stances that she implicitly adopts for her drama rely on a female's ability to metamorphose herself to represent a particular quality in order to offer a comprehensive portrait of the inadequate, intratextual fashioning not only of the creation of woman, but of the fashioning of man as well. While the female members of the chorus do not go beyond a juxtaposition of their innate characters to Nature's daughters, the male members of the cast are more specific in their reference to current mores and the secularisation of symbolism of hitherto mythic proportions, as in the desacralisation and disenchantment of the sword as a symbol of honour and protection, and by extension Christ, as well. With the exception of those magnificent figures introducing elaborate philosophical contemplation, the female allegories largely represent the pettiness and emotional confusion of earthly existence. Only the character of Tell-Truth corrects the slanderous statements that, among others, the characters Detractor, Malicious, and Spitefull articulate. At no time, however, are the statements of the one prioritised over those of the other. Tell-Truth, at the beginning of the first part of the play, states unequivocally that: "The Lady Natures Daughters are the only Ladies that are admired, praised, adored, worshiped, and sued to; all other women are despised.” Beauty, Love, and Wit represent emanations of Nature whose irresistible attractiveness not only inspires admiration and worship as the encomiastic actions due to divinity; rather, translated into a human context, they can trigger jealousy and discontent, the result of an awareness of their inferiority to these deities. The one-dimensional and static allegorical characters are inscribed with a function and task that they cannot escape or transmute. Unchangeable, these figures give voice to their ideational essence but cannot go beyond verbalising their specific natures. While they form a faction, this faction is neither harmonious, nor is it informed by a unity of 
purpose; it is characterised by discord, whereas the superior deities Beauty, Love, and Wit have the ability to inspire human beings holistically with a sense of fulfilment. Cavendish conceives of a type of being that amalgamates these qualities and thereby is elevated above mere humanity to a proto-mythic existence that partakes of the essence of nature.

Fundamentally, Cavendish expects that her readers (and the audience of the chorus specifically), depending on their own elevated or corrupted nature, will take sides. Modally, the utterances of such allegorical personifications as Detractor are passionate and fuelled by jealousy; by contrast, the monolithic and oracular figures of discourse, including Madame Grand Esprit, facilitate discussion and critical engagement by means of a concatenation of questions that overwhelm and contrast strikingly with the spontaneous and unpremeditated lesser allegories. Whereas she appears to possess mythic insight, offering a closely knit logical argument that is supertemporal and concerned with esoteric issues, the others are characterised by perverted self-centredness since their self-love — a natural (or naturally divine) quality — and desire for worship and adoration does not receive a response. As a consequence, these female allegories engage in a destructive campaign of slander and detraction, intent on approximating themselves with, and narrowing the distance between, themselves and truth by lessening the mythic forces of attraction with which these daughters of Nature are endowed. Cavendish punctuates her drama with these kinds of discursive monumentalising personae which serve as clear caesurae in a dramatic polyphony that offers the perspectives of a number of allegorical instances but does little to synthesise or interrelate these voices. In this regard, the private reading practice is a less advantageous form of consumption of the dramatic work than one that utilises presentational conventions such as those of the Greek chorus, where the inherent dynamics of movement are clearly an important part of the presentational makeup. The implicit hierarchical ordering, too, can be rendered far more meaningfully if a philosophical emanation of Nature presides over the 
action of the drama. The dramatic structure accommodates at least three different referential planes that interconnect Cavendish's universe of meaning - the allegorical, the divinephilosophical, and the mentality-historical and traceable human elements engendered especially in scenes that discuss and exemplify the complex notions of love and virtue. Although the exchanges between the minor allegorical personages follow a dialogic structure, the different utterances do not propel any action forward. Rather, they remain self-contained and appear to be absorbed into a format of miscellaneity that ultimately is embedded in a process of metonymical identification and a mythic ur-narrative. The latter has been severed from its originating mythic contexts as a result of secularisation and the human distrust in the gods and other human beings.

While the first scene of the play introduces the minor allegorical personifications' disadvantageous comparisons of themselves to Nature's daughters, the second scene shifts modes and relates a dialogue between Monsieur Esperance and his wife. Madame Esperance protests her love for her husband in response to his reproach that she does not sufficiently, externally manifest her love for him. The thoughtless husband is corrected in his false belief in how true love should manifest itself and this dialogue, ending in the wife's resolving the husband's complaint, like a leitmotif serves to underpin the practical and philosophical exemplification of love as both concept and experience. Cavendish relativises the significance of appearance and recommends rational reflection and philosophical internalisation. Intent on characterising the nature of man, she introduces two further case studies, one - in scene 3 - that focuses on two gentlemen's desire to encounter Wit by listening to her discoursing in public, thereby paying homage to one of the daughters of Nature and emulating the ideals that she advances. Scene 4 introduces two other male figures, placed at different ends of the social spectrum-Monsieur Nobilissimo and Monsieur Poverty — and illustrates the former's beneficence and dignity as well as the latter's frank 
admission of his need for support. The final scene of the first act introduces a dialogue between Mademoiselle Amor and Monsieur Addresser in which Cavendish once more treats the subject of love.

The brief description of the different ideational and contextual foci in the first act alone offers an indication of the modal complexity of Cavendish's play. She connects scenes as different as the dialogic pageant of allegorical personifications with Monsieur's Nobilissimo's greatness of soul. In all the characters, she reveals a dual agenda: to define a concept in allegorical fashion but to anchor this concept in the mentality of her period and her understanding of a postlapsarian world and the challenges it provides for mankind. Very much like the disharmonious world of Nature in Poems and Fancies, Cavendish's characters seek to establish a world in which they can exist meaningfully and not merely as dualistic absolutes in a creational setup that is presided over by the extratextual Nature and ever omnipresent emanations of her daughters, Beauty, Love and Wit.

The shift, in Act II, Scene 2, to the monologic discourse that Mademoiselle Grand Esprit delivers represents a concentration of argumentative power and insight that all the previous scenes lack. She imploringly invokes Great Fortune to "open every hearing door" and to "let their [listeners'] Ears be fixt, as if their sight / Did view my words, till on their Ears they light.” This ritualistic apostrophe and its implied petition for her audience's attention establish Mademoiselle Grand Esprit as a mythico-philosophical priestess who undertakes to investigate the mysteries of the creation. The synesthetic metaphor she utilises underscores the potentially transformative power of her words; her words have proto-visual power and are imprinted not only potentially on the page but on the audience's minds as well. After this monumental figure's apostrophe to Fortune, the tone of her discourse could not be more different: it is systematic and does not develop the mythic strain initiated by her establishing a relationship with Fortune. Although the structure of the discourse is rendered in 
less spontaneous and subjective ways than the parts spoken by the earlier allegorical characters, Mademoiselle Grand Esprit is preoccupied with investigating the origins of man. She sets out to examine Man's Ignorance and offers to provide answers that man, including Cavendish's hybrid allegorical creation, has been unable to find.

Among the different parts of her discourse, she aims to consider an epistemological issue:

What Man is, or ever was, that knows how he was formed, or of what composition, or what is that he calls a Rational Soul? Whether it is imbodyed, or not imbodyed? Whether it is Divine, or Mortal? Whether it proceeds from the Gods, or was created by Nature? Whether it shall live for ever, or shall have a period? Whether it shall live in Knowledge, or ly in Ignorance? Whether it be capable of pain, or pleasure? Whether it shall have a residing place, or no certain place assigned? Or if it have none, where it shall wander? Or if it have, where that residing place is.

These questions contrast strikingly with the experiential, divine meaning that Beauty, Love and Wit are capable of conveying. Mademoiselle Grand Esprit seeks to demystify these figures in order to create a scientific-philosophical myth of the creation, purpose and fate of man. The conflicting voices that build up a sense of disharmonious polyphony are seemingly counteracted by the authoritative, philosophical statements of a rationale to understand man and woman in all their complexity. Ultimately, Cavendish's mythopoetics promote the questioning of the meaning of the being that is man. The play's continuous introduction of new voices and subjects that are discussed and elaborated in various (not often clearly connected) ways underpins the mystery that the author identified in man and woman and that 
even a mythic figure such as Mademoiselle Grand Esprit could not fully disenchant, explain, or rationalise.

Madame Grand Esprit is conceptualised in a way that is reminiscent of Cavendish's own textual performance and its various strategies of self-construction. Unity and connectedness of ideas is only established through the meaningful act of Cavendish's utterance, and the contributions in this special issue offer novel and persuasive ways to explain an early modern woman's unique and often underestimated self-fashioning.

\section{References}

Cottegnies, Line. “The 'Native Tongue' of the 'Authoress': The Mythical Structure of Margaret Cavendish's Autobiographical Narrative." In Authorial Conquests: Essays on Genre in the Writings of Margaret Cavendish. Edited by Line Cottegnies and Nancy Weitz. Madison, NJ: Fairleigh Dickinson University Press, 2003. 